\title{
Editorial
}

\section{Introduction to CIB W14 Special Issue}

\author{
George V. Hadjisophocleous*, Department of Fire Safety Engineering, \\ Carleton University, Ottawa CIB W014, Canada
}

CIB is the acronym of the abbreviated French (former) name: "Conseil International du Bâtiment" (in English this is: International Council for Building). In 1998, the abbreviation has been kept but the full name changed into: International Council for Research and Innovation in Building and Construction.

CIB was established in 1953 as an Association whose objectives were to stimulate and facilitate international cooperation and information exchange between governmental research institutes in the building and construction sector, with an emphasis on those institutes engaged in technical fields of research. CIB has since developed into a worldwide network of over 5,000 experts from about 500 member organizations active in the research community, in industry or in education, who cooperate and exchange information in over $50 \mathrm{CIB}$ Commissions covering all fields in building and construction related research and innovation.

CIB Commissions initiate projects for R\&D and information exchange, organize meetings and produce publications. These meetings can be Commission meetings for members only or international symposia and congresses open to all. Publications can be proceedings, scientific or technical analyses and international state of the art reports.

One of the Commissions of CIB is CIB W014-Fire, which has 57 members from 27 countries. CIB W014 promotes and supports science-based fire safety engineering and its use for performance based fire safety designs. The Objectives of this CIB Working Commission are:

- to provide an ongoing research focus and promote international collaboration for the development of a sound scientific and technical basis for fire safety engineering (FSE) methods.

- to promote fire safety engineering methods and their use with performance based codes.

- to provide fire safety technology input to the other CIB Commissions as appropriate.

- to exchange fire safety engineering outputs internationally, including the standards community.

* Correspondence should be addressed to: George V. Hadjisophocleous, E-mail: george_ hadjisophocleous@carleton.ca 
To meet those objectives CIB W014 launches projects with well-defined scopes and limited time schedules, publishes the output of its work as CIB Publications, in international journals and in workshop or conference proceedings, provides a forum for networking among its members, organizes workshops with topics in the context of the work program, initiates the CIB co-sponsorship of conferences that serve the purpose of the commission, facilitates its members to circulate information on ongoing and completed research projects and research publications and liaises with organizations having similar interests.

CIB W014 had developed a research program, which focuses on a number of areas which are of interest to its members and where International collaboration is essential in achieving the planned outputs that can be used as inputs for the development of International Standards and Building Codes. The projects deal with:

- Design Fires

- Fire performance of materials

- Structural performance in fire-connections

- Structural performance in fire-fire induced progressive collapse

- Human behaviour and abilities

- Performance criteria for performance based fire safety design

CIB W014 solicited papers for this special issue of Fire Technology that were representative of its international activities. From the high quality technical submissions six papers have been chosen as representative of the type of work promoted by the working commission. They have all been through the rigorous peer-review process of the journal. 